\title{
AL-IQTISHADIYAH
}

Jurnal Ekonomi Syariah dan Hukum Ekonomi Syariah

E-ISSN: 2621-0274; P-ISSN: 2442-2282

Volume 7, Nomor 1, Juni 2021

\section{Pendekatan Balanced Scorecard dalam Mengukur Kinerja Baitul Mal wa Tamwil Amanah Kota Banjarmasin}

\section{Difi Dahliana}

Fakultas Ekonomi dan Bisnis Islam, Universitas Islam Negeri Antasari, Indonesia. E-mail: difidahliana@uin-antasari@ac.id

\begin{tabular}{|c|c|}
\hline ARTICLE INFO & ABSTRACT \\
\hline $\begin{array}{l}\text { Keywords: } \\
\text { Balanced scorecard; } \\
\text { BMT; Performance } \\
\text { measurement }\end{array}$ & $\begin{array}{l}\text { Performance measurement that only focuses on the financial health } \\
\text { aspect as applied by most BMT, does not provide comprehensive } \\
\text { results. Contemporary performance measurement known as the } \\
\text { Balanced Scorecard (BSC) is more comprehensive because it does not } \\
\text { only focus on aspects of financial health but also non-financial aspects. } \\
\text { This study aims to measure and evaluate the performance of BMT } \\
\text { Amanah with approach BSC consisting of financial, customer, } \\
\text { perspectives internal business processes, as well as growth and } \\
\text { learning. After processing and quantitative descriptive analysis, the } \\
\text { results show that: 1) the performance of the financial perspective has } \\
\text { a score of 2.3, which means that it is not good; 2) the performance of } \\
\text { the customer perspective has a score of 3.4 which means it is quite } \\
\text { good; 3) the performance of the internal business process perspective } \\
\text { has a score of } 2.2 \text { which means it is not good; } 4 \text { ) the performance of the } \\
\text { growth and learning perspective has a score of } 3.1 \text { which means it is } \\
\text { quite good. Thus, BMT Amanah's strategic objectives, which are too } \\
\text { people-centric, resulting in the neglect of the business process and } \\
\text { financial perspectives, must be evaluated. } \\
\text { ABSTRAK }\end{array}$ \\
\hline $\begin{array}{l}\text { Kata Kunci: } \\
\text { Balanced scorecard; } \\
\text { BMT; Pengukuran } \\
\text { kinerja }\end{array}$ & $\begin{array}{l}\text { Pengukuran kinerja yang hanya fokus pada aspek kesehatan keuangan } \\
\text { seperti yang diterapkan oleh kebanyakan BMT, tidak memberikan } \\
\text { hasil yang komprehensif. Pengukuran kinerja kontemporer yang } \\
\text { dikenal dengan Balanced Scorecard (BSC) lebih komprehensif karena } \\
\text { menekankan keseimbangan dan keterkaitan antar aspek keuangan } \\
\text { dan non keuangan. Penelitian ini bertujuan untuk mengukur dan } \\
\text { mengevaluasi kinerja BMT Amanah dengan pendekatan BSC yang } \\
\text { terdiri dari perspektif keuangan, pelanggan, proses bisnis internal, } \\
\text { serta pertumbuhan dan pembelajaran. Setelah dilakukan pengolahan } \\
\text { dan analisis deskriptif kuantitatif, hasilnya menunjukkan bahwa: } 1 \text { ) } \\
\text { kinerja perspektif keuangan skornya } 2,3 \text { artinya kurang baik; } 2 \text { ) kinerja } \\
\text { perspektif pelanggan skornya } 3,4 \text { artinya cukup baik; } 3 \text { ) kinerja } \\
\text { perspektif proses bisnis internal skornya } 2,2 \text { artinya kurang baik; } 4) \\
\text { kinerja perspektif pertumbuhan dan pembelajaran skornya } 3,1 \\
\text { artinya cukup baik. Dengan demikian, sasaran strategik BMT Amanah } \\
\text { yang terlalu people-centric sehingga mengakibatkan perspektif proses } \\
\text { bisnis dan perspektif keuangan menjadi terabaikan, harus dievaluasi. }\end{array}$ \\
\hline
\end{tabular}


Jurnal Ekonomi Syariah dan Hukum Ekonomi Syariah

\section{Pendahuluan}

BMT adalah lembaga keuangan syariah berskala mikro yang khas Indonesia karena kegiatan operasionalnya seperti koperasi. ${ }^{1}$ Keberadaan BMT di tengah masyarakat diperlukan karena beberapa alasan. Pertama, adanya BMT dapat menjauhkan masyarakat dari praktek ekonomi yang tidak Islami. Kedua, BMT dapat membina dan membantu pendanaan usaha kecil. Ketiga, BMT dapat membantu melepaskan ketergantungan masyarakat pada rentenir. Keempat, BMT dapat mewujudkan keadilan ekonomi masyarakat dengan distribusi yang merata karena BMT diharapkan dapat menjangkau lapisan masyarakat yang tidak terakomodir oleh sistem perbankan. ${ }^{2}$ BMT menyediakan layanan keuangan bagi masyarakat yang unbankable, sehingga BMT merupakan bagian dari penggerak perekonomian Indonesia, yang keberadaannya bertujuan untuk mendorong sektor usaha mikro dan kecil. ${ }^{3}$ Dalam sebuah penelitian terhadap persepsi nasabah BMT di kota Banjarmasin, menunjukkan bahwa BMT telah menjalankan perannya dengan baik sebagai motor penggerak perekonomian masyarakat lapisan bawah di kota Banjarmasin. ${ }^{4}$

Perkembangan BMT semakin pesat, terbukti secara kuantitas pada tahun 2018 terdapat sekitar 4.500 BMT di seluruh Indonesia. ${ }^{5}$ Namun, ditengah perkembangan dan praktiknya yang semakin meluas itu, BMT tidak luput dari persoalan dan tantangan yang berpotensi menghambat optimalisasi perannya di masyarakat, terutama terkait dengan sustainability lembaga. ${ }^{6}$ Menurut Indra sustainabilitas BMT dipengaruhi oleh sustainabilitas kelembagaan (institutional sustainability), sustainabilitas keuangan (financial sustainability) dan dukungan eksternal. ${ }^{7}$ Ubaidillah menyebutkan bahwa sustainabilitas BMT dipengaruhi oleh aspek sumber daya insani, permodalan, jangkauan pasar, regulasi, pengawasan dan infrastruktur. la merekomendasikan dalam mempertahankan sustainabilitas, BMT harus meningkatkan kinerja BMT dengan memperhatikan aspek-aspek tersebut. ${ }^{8}$

\footnotetext{
1 Herawati, “Pengukuran Kinerja Koperasi Berbsis Balanced Scorecard," 63, diakses 4 Juni 2021, http://ojs.unik-kediri.ac.id/index.php/ekonika/article/view/33.

2 Difi Dahliana, “Persepsi Nasabah Terhadap Peran BMT Kota Banjarmasin," Jurnal Al lqtishadiyah 6, no. 1 (1 Juli 2020): 44, https://doi.org/10.31602/al.

${ }^{3}$ Sharianews.com, “Menyongsong Perkembangan BMT di Indonesia," Sharia News, diakses 3 Juni 2021, menyongsong-perkembangan-bmt-di-indonesia.

${ }^{4}$ Dahliana, “Persepsi Nasabah Terhadap Peran BMT Kota Banjarmasin," 44.

5 “Penyusunan Roadmap Pengembangan Baitul Maal Wat Tamwil (BMT) Di Indonesia," Komite Nasional Ekonomi dan Keuangan Syariah, diakses 3 Juni 2021, https://knks.go.id/isuutama/6/penyusunanroadmap-pengembangan-baitul-maal-wat-tamwil-bmt-di-indonesia.

6 “Penyusunan Roadmap Pengembangan Baitul Maal Wat Tamwil (BMT) Di Indonesia."

${ }^{7}$ Yus Indra, "Strategi Mewujudkan Kemandirian Sektor Finansial Lokal Melalui Sustainabilitas Lembaga Keuangan Mikro Syariah (Baitul Maal Watamwil, BMT)," Jurnal Terapan Abdimas 3, no. 2 (13 Juli 2018): 85-90, https://doi.org/10.25273/jta.v3i2.2793.

8 Ubaidillah Ubaidillah, "Analisis Sustainabilitas Lembaga Keuangan Mikro Syariah Di Kabupaten Banyumas," Al-Mashrof: Islamic Banking and Finance 2, no. 1 (1 Mei 2021): 76-95.
} 
Persoalan ini harus dipertimbangkan oleh praktisi BMT yang ada di kota Banjarmasin. Mengingat pentingnya peningkatan kinerja dalam upaya menjaga sustainabilitas, maka BMT perlu mengubah pendekatan yang digunakan dalam mengukur kinerja. Pengukuran kinerja konvensional yang hanya fokus pada aspek kesehatan keuangan tidak lagi relevan di tengah semakin kompleksnya kondisi lingkungan organisasi, ${ }^{9}$ sehingga diperlukan pendekatan yang lebih komprehensif yang tidak hanya bertumpu pada penilaian aspek keuangan semata. ${ }^{10}$ Pada tahun 1992, Kaplan dan Norton menciptakan alat manajemen kontemporer bernama Balanced Scorecard (BSC) generasi pertama yang fokus pada pengukuran kinerja. ${ }^{11}$ Ada empat keunggulan yang membedakan BSC dengan metode pengukuran kinerja konvensional lainnya, yaitu komprehensif, koheren, seimbang dan terukur. ${ }^{12}$ Keunggulannya itu dapat dilihat dari variabel pengukuran kinerja yang mencakup : 1) perspektif keuangan; 2) perspektif pelanggan, 3) perspektif proses bisnis internal; 4) perspektif pertumbuhan dan pembelajaran. ${ }^{13}$ Pada awalnya BSC banyak digunakan oleh perusahaan berskala besar, namun sekarang sudah meluas ke perusahaan kecil, hingga organisasi sosial.

Penelitian tentang pengukuran kinerja BMT dengan pendekatan BSC sudah banyak dilakukan. Pertama, penelitian Reifansyah dan Pradhanawati terhadap kinerja BMT Ar Rahmah Kabupaten Sukoharjo yang bertujuan untuk mengetahui periode tahun dengan kinerja terbaik dengan membandingkan kinerja dari tahun ke tahun. ${ }^{14}$ Sedangkan penelitian yang penulis lakukan tidak bertujuan untuk membandingkan kinerja BMT Amanah dari tahun ke tahun. Kedua, penelitian Budi Utami terhadap kinerja BMT As-Salam di lingkungan Pondok Pesantren Babussalam Kalibening Mojoagung Jombang. ${ }^{15}$ Penelitian tersebut dilakukan untuk mencari nilai rata-rata pencapaian kinerja tanpa melakukan scoring terhadap masing-masing indikator, sementara penulis menerapkan scoring untuk mempermudah interpretasi dalam analisis data. Ketiga, penelitian Dian Masyita yang ruang lingkup penelitiannya lebih luas dibanding penelitian penulis. la melakukan penelitian terhadap kinerja dari 18 lembaga keuangan di kota Bandung yang memberikan layanan kredit dan pembiayaan

\footnotetext{
${ }^{9}$ Nurul Huda, Ivo Sabrina, dan Efendy Zain, "Pengukuran Kinerja Perbankan Syariah Dengan Pendekatan Balance Scorecard.," Etikonomi 12, no. 1 (1 April 2013): 22, https://doi.org/10.15408/etk.v12i1.1900.

${ }^{10}$ Barbara Gunawan, "Balanced Scorecard: Perspektif Baru Dalam Menilai Kinerja Organisasi," Journal of Accounting and Investment 1, no. 1 (2000): 41-51.

${ }^{11}$ Suwardi Luis, Step by Step in Cascading Balanced Scorecard to Fungtional Scorecards (PT. Gramedia Pustaka Utama, Jakarta: 2008), h. 16-18.

12 Lianto Lianto, “Keunggulan Balanced Scorecard Sebagai Sistem Manajemen Strategis Yang Holistik," MABIS 2, no. 2 (13 Mei 2016), http://journal.widyadharma.ac.id/index.php/mabis/article/view/53.

13 Gunawan, "Balanced Scorecard."

14 Muhammad Hiksa Reisfansyah dan Ari Pradhanawati, "Pengukuran Kinerja Perusahaan Dengan Metode Balanced Scorecard Pada BMT Syariah Ar Rahmah Kabupaten Sukoharjo," Jurnal IImu Administrasi Bisnis 6, no. 3 (2017): 580-89.

${ }^{15}$ Budi Utami, "Pengukuran Kinerja Lembaga Keuangan Syariah BMT As-Salam Dengan Menggunakan Metode Balanced Scorecard," Bisman (Bisnis Dan Manajemen): The Journal of Business and Management 2, no. 1 (22 Februari 2019): 82-93.
} 
Jurnal Ekonomi Syariah dan Hukum Ekonomi Syariah

mikro termasuk diantaranya adalah BRI, BPR, BPRS dan BMT. Tujuannya untuk mengetahui peringkat dan faktor yang mempengaruhinya. Hasilnya menunjukkan bahwa BRI memiliki kinerja terbaik, sedangkan BMT menunjukkan struktur kelembagaan yang lemah menurut standar BSC. ${ }^{16}$ Penulis tertarik melakukan penelitian ini karena belum menemukan adanya penelitian tentang pengukuran kinerja BMT di kota Banjarmasin yang menggunakan pendekatan BSC.

\section{Landasan Teori}

David Norton dan Robert S. Kaplan memperkenalkan Balanced Scorecard (BSC) pada tahun $1992 .{ }^{17}$ Pencapaian sebuah perusahaan tidak hanya diwujudkan oleh aset fisik keuangan tetapi juga aset tak berwujud seperti hubungan dengan pelanggan, proses yang berkualitas, produk dan jasa yang inovatif, keahlian karyawan dan sebagainya yang tidak dapat diukur oleh pengukuran kinerja keuangan semata. ${ }^{18}$ Kaplan dan Norton meyakini bahwa kinerja yang tidak dapat diukur, tidak akan dapat diperbaiki, sementara pengukuran kinerja adalah hal mendasar bagi perusahaan. Manajemen perusahaan harus mengintegrasikan pengukuran aset tidak berwujud ke dalam sistem manajemennya. ${ }^{19}$

BSC memiliki keunggulan yang menjadikan sistem manajemen strategik sekarang berbeda secara signifikan dengan sistem manajemen strategik tradisional yang hanya berfokus ke sasaran-sasaran yang bersifat keuangan. Pertama, komprehensif. BSC memandang organisasi secara holistik, BSC memperluas perspektif yang dicakup dalam perencanaan strategik, dari sebelumnya yang hanya terbatas pada perspektif keuangan, meluas ke tiga perspektif yang lain: customer, proses bisnis intern, serta pembelajaran dan pertumbuhan. ${ }^{20}$ Kinerja keuangan yang sesungguhnya adalah dihasilkan dari perspektif pelanggan, proses internal serta pembelajaran dan pertumbuhan, ia berasal dari usaha nyata dalam bisnis, sehingga kinerja keuangan akan berlipat ganda dan berjangka panjang.

Kedua, koheren. BSC mewajibkan personel untuk membangun hubungan sebab akibat (causal relationship) di antara berbagai sasaran strategik yang dihasilkan dalam perencanaan strategik. Setiap sasaran strategik yang ditetapkan dalam perspektif non keuangan, secara langsung ataupun tidak harus memiliki hubungan kausal dengan

\footnotetext{
${ }^{16}$ Dian Masyita, "Islamic microfinance institutions in Indonesia and the challenges in the supply chain perspectives," International Journal of Supply Chain Management 6 (1 Januari 2017): 341-50.

17 Deni Hadiansah dkk., “Membaca Perspektif Balanced Scorecard," 15 Februari 2021, 2, https://repository.azkahafidzmaulana.org/publications/339651/.

18 Cokro Suryo Atmojo, "The Balanced Scorecard," diakses 3 Juni 2021, https://www.academia.edu/29202237/The_Balanced_Scorecard.

19 Robert S. Kaplan, "Conceptual Foundations of the Balanced Scorecard," dalam Handbooks of Management Accounting Research, ed. oleh Christopher S. Chapman, Anthony G. Hopwood, dan Michael D. Shields, vol. 3, Handbook of Management Accounting Research (Elsevier, 2009), 1253-69, https://doi.org/10.1016/S1751-3243(07)03003-9.

${ }^{20}$ Lianto, “Keunggulan Balanced Scorecard Sebagai Sistem Manajemen Strategis Yang Holistik," 1.
} 
sasaran keuangan. Ketiga, seimbang. BSC menekankan keseimbangan berbagai indikator yang tercakup dalam empat perspektif ${ }^{21}$. Jika sasaran lebih difokuskan pada perspektif proses bisnis serta pembelajaran dan pertumbuhan disebut terlalu berfokus intern, sehingga pelanggan dan keuangan terabaikan, dampaknya adalah kepuasan pelanggan yang nantinya mempengaruhi kemampuan perusahaan dalam menghasilkan kinerja keuangan. Jika lebih difokuskan pada perspektif keuangan dan pelanggan disebut terlalu berfokus ekstern, yang mengakibatkan proses bisnis serta pembelajaran dan pertumbuhan terabaikan, sehingga dapat mempengaruhi kinerja keuangan dalam jangka panjang. Sasaran strategik yag lebih difokuskan pada perspektif pelanggan dan perspektif pertumbuhan pembelajaran disebut terlalu berfokus ke orang (people centric), yang mengakibatkan perspektif proses dan keuangan terabaikan, sehingga mempengaruhi kinerja keuangan perusahaan dalam jangka panjang. Sedangkan jika lebih difokuskan pada perspektif proses da keuangan, disebut terlalu berfokus ke proses (process centric) yang mengakibatkan perspektif customer dan pembelajaran pertumbuhan terabaikan, sehingga mempengaruhi kinerja perusahaan dalam menghasilkan kinerja keuangan jangka panjang. Keempat, terukur. BSC mengukur sasaran-sasaran strategik yang sulit untuk diukur, seperti perspektif pelanggan, proses bisnis intern, serta pembelajaran dan pertumbuhan. Dalam pendekatan BSC, sasaran di ketiga perspektif non keuangan tersebut ditentukan ukurannya agar dapat dikelola, sehingga dapat diwujudkan. ${ }^{22}$

\section{Gambar 1. Balanced Scorecard Matrix ${ }^{23}$}

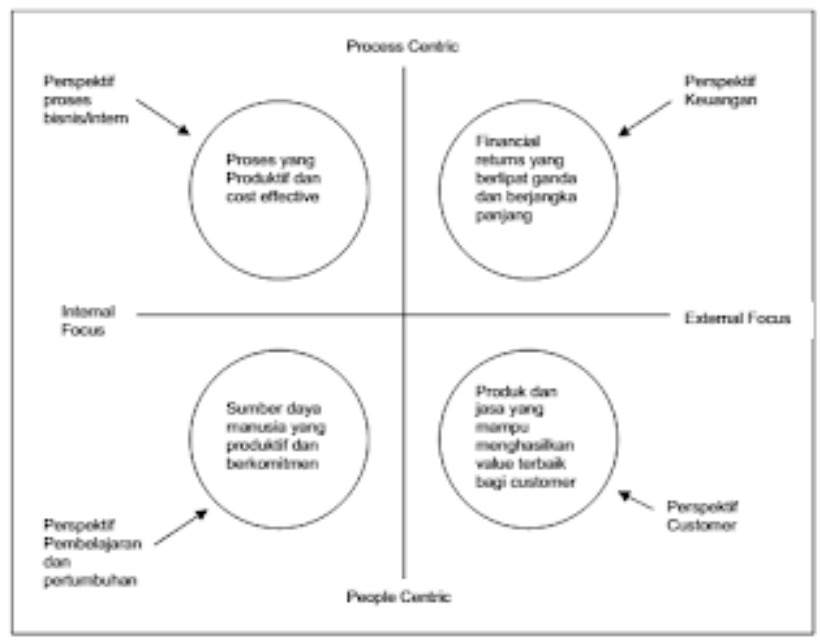

${ }^{21}$ Utami, "Pengukuran Kinerja Lembaga Keuangan Syariah BMT As-Salam Dengan Menggunakan Metode Balanced Scorecard," 84.

${ }^{22}$ Mulyadi, Sistem terpadu pengelolaan kinerja personil berbasis balanced scorecard (UPP STIM YKPN, 2018), 18-42.

23 Mulyadi, 22. 
Berdasarkan metode Balanced Scorecard variable kinerja terdiri dari empat perspektif yaitu perspektif keuangan, perspektif pelanggan, perspektif proses bisnis internal, serta perspektif pembelajaran dan pertumbuhan. ${ }^{24}$

Scorecard mengukur kinerja perusahaan pada empat perspektif yakni:

1. Perspektif Finansial

Keuangan organisasi atau perusahaan dapat dilihat dari dua sudut pandang, yaitu jangka pendek dan jangka panjang. Dalam pendekatan keuangan yang bertujuan jangka pendek, strategi yang digunakan adalah peningkatan produktifitas, meliputi upaya-upaya yang dapat dilakukan agar produktifitas dapat optimal. Strategi ini dapat dicapai dengan perbaikan struktur biaya dan pemaksimalan utilisasi asset. dalam pendekatan keuangan yang bertujuan jangka panjang dilakukan strategi khusus yang disebut strategi pertumbuhan. Strategi ini meliputi peningkatan pendapatan dan peningkatan nilai bagi pelanggan ${ }^{25}$

BSC tetap menggunakan perspektif finansial karena ukuran finansial sangat penting dalam memberikan ringkasan konsekuansi tindakan ekonomis yang sudah diambil. Ukuran kinerja finansial memberikan informasi apakah strategi perusahaan, implementasi dan pelaksanaannya memberikan kontribusi atau tidak bagi peningkatan laba perusahaan. ${ }^{26}$

Penerapan BSC seharusnya akan mendorong unit bisnis untuk mengaitkan tujuan finansial dengan strategi korporasi. Tujuan finansial dan menjadi fokus tujuan dan ukuran di semua perspektif scorecard lainnya. Setiap ukuran terpilih harus merupakan bagian dari hubungan sebab akibat yang pada akhirnya akan meningkatkan kinerja keuangan. Setiap unit yang berbeda mungkin akan memerlukan strategi yang berbeda pula. Sehingga ketika pengembangan perspektif finansial dimulai, para eksekutif unit bisnis dapat menentukan ukuran finansial yang sesuai untuk unit bisnis yang ada. Untuk sebagian besar perusahaan, berbagai tema finansial seperti peningkatan pendapatan, penghematan biaya dan peningkatan produktifitas, peningkatan pemanfaatan aktiva, serta pengurangan risiko dapat memungkinkan terciptanya keterkaitan di antara keempat perspektif scorecard. ${ }^{27}$

\section{Perspektif Pelanggan}

Di masa lalu, perusahaan memusatkan diri pada kapabilitas internal dengan mengandalkan kinerja produk dan inovasi teknologi. Tetapi, perusahaan yang

\footnotetext{
${ }^{24}$ Robert Kaplan dan David P. Norton, Balanced Scorecard Menerapkan Strategi Menjadi Aksi (Jakarta: Erlangga, 2000), h. 7.

${ }^{25}$ Suwardi Luis, Step by step in cascading balanced scorecard to functional scorecardsS (PT. Gramedia Pustaka Utama, 2008), 25-26.

${ }^{26}$ Robert S. Kaplan dan David P. Norton, Menerapkan Strategi Menjadi Aksi: Balanced Scorecard (Jakarta: Erlangga, 2000), 23.

${ }^{27}$ Ibid, h. 41-54.
} 
tidak memahami kebutuhan pelanggan akan memudahkan para pesaing untuk menyerang melalui penawaran produk dan jasa yang lebih baik sesuai preferensi pelanggan. Oleh karena itu, banyak perusahaan yang saat ini berpindah fokus secara eksternal kepada pelanggan. Dalam perspektif pelanggan BSC, selain keinginan untuk memuaskan dan menyenangkan pelanggan, namun juga menerjemahkan misi dan strategi perusahaan ke dalam tujuan yang spesifik yang berkenaan dengan pelanggan dan segmen. ${ }^{28}$

Perspektif ini biasanya terdiri atas beberapa ukuran utama keberhasilan perusahaan dari strategi yang dirumuskan dan dilaksanakan dengan baik. Ukuran utama tersebut terdiri atas kepuasan pelanggan, retensi pelanggan (kemampuan mempertahankan pelanggan lama), akuisisi pelanggan (kemampuan memperoleh pelanggan baru), profitabilitas pelanggan, dan pangsa pasar di segmen sasaran. ${ }^{29}$

3. Perspektif Proses Bisnis Internal

Dalam perspektif proses bisnis internal, para eksekutif mengidentifikasi berbagai proses internal penting yang harus dikuasai dengan baik oleh perusahaan. Ukuran proses bisnis internal berfokus kepada berbagai proses internal yang akan berdampak besar kepada kepuasan pelanggan dan pencapaian tujuan finansial perusahaan.

Setiap bisnis memiliki rangkaian proses tertentu untuk menciptakan nilai bagi pelanggan dan memberikan hasil finansial yang baik. Namun secara umum model rantai tersebut terdiri atas tiga proses bisnis utama yaitu inovasi, operasi dan layanan purna jual. Dalam proses inovasi, unit bisnis meneliti kebutuhan pelanggan yang sedang berkembang atau yang masih tersembunyi, dan kemudian menciptakan produk atau jasa yang akan memenuhi kebutuhan tersebut. Proses operasi, langkah utama kedua dalam rantai nilai, adalah tempat di mana produk dan jasa diproduksi dan disampaikan kepada pelanggan, dikaitkan dengan pengukuran waktu, mutu, dan biaya. Proses operasi secara histories telah menjadi fokus sebagian besar sistem pengukuran kinerja perusahaan. Rantai ketiga adalah layanan kepada pelanggan setelah penjualan atau penyampaian produk dan jasa. $^{30}$

4. Perspektif Pembelajaran dan Pertumbuhan

Tujuan dalam persfektif pembelajaran dan pertumbuhan merupakan faktor pendorong dihasilkannya kinerja yang istimewa dalam tiga perspektif lainnya. Perspektif inilah yang menyediakan infrastruktur yang memungkinkan tujuan dari tiga perspektif lainnya dapat tercapai. Ada tiga kategori utama yang menjadi ukuran dalam perspektif ini yaitu kapabilitas pekerja, kapabilitas sistem informasi, serta motivasi, pemberdayaan dan keselarasan. Sebagian besar perusahaan menetapkan tujuan pekerja yang ditarik dari tiga pengukuran utama yang berlaku

\footnotetext{
${ }^{28}$ Kaplan dan Northon, Menerapkan..., h. 55-56.

${ }^{29}$ Ibid, h. 23.

${ }^{30}$ lbid, h. 83.
} 
umum. Ketiga ukuran itu adalah kepuasan pekerja, retensi pekerja, dan beberapa faktor mengenai kebutuhan dan keinginan pegawai, yakni: gaji yang baik, pekerjaan yang aman, rekan sekerja yang kompak, penghargaan terhadap pekerjaan, pekerjaan yang berarti, kesempatan untuk maju, pimpinan yang adil dan bijaksana, pengarahan dan perintah yang wajar, dan organisasi atau tempat kerja yang dihargai oleh masyarakat. ${ }^{31}$ Beberapa contoh Key Performance Indicator (KPI) atau ukuran lainnya seperti Training Coverage yaitu persentase karyawan yang ikut training., jumlah hari pelatihan, total peningkatan revenue terhadap total peningkatan kompensasi karyawan dan sebagainya. ${ }^{32}$

\section{Metode Penelitian}

Penelitian ini tergolong field research untuk menggali data tentang: 1) Perspektif keuangan, indikatornya struktur permodalan, kualitas aktiva produktif, likuiditas, efisiensi dan rentabilitas; 2) Perspektif pelanggan, indikatornya tingkat kepuasan, tingkat retensi dan tingkat akuisisi; 3) Perspektif proses bisnis internal, keseimbangan portofolio pembiayaan, financing process dan service error rate; 4) Perspektif pertumbuhan pembelajaran, indikatornya tingkat kepuasan, tingkat turn over, training coverage dan absensi. Teknik pengumpulan datanya wawancara, angket, observasi dan dokumentasi. Analisis statistik dilakukan untuk mengukur validitas dan reliabilitas angket serta mengukur tingkat kepuasan pelanggan dan karyawan. Adapun pengolahan data dilakukan dengan metode analisis deskriptif kuantitatif terdiri dari tahap editing, coding, tabulating dan interpretasi. Kriteria penilaian mengacu pada pedoman penilaian tingkat kesehatan jasadiyah dan ruhiyah BMT, dimana skor $<1,50$ diinterpretasikan dengan kategori tidak baik, skor 1,50-2,49 kurang baik, skor 2,5 3,49 cukup baik, dan skor $3,50-4,00$ tergolong baik. ${ }^{33}$

\section{Pembahasan}

\section{Perspektif Keuangan}

Kinerja perspektif keuangan diukur menggunakan indikator dan pembobotan sesuai tata cara penilaian kesehatan keuangan BMT oleh PINBUK. ${ }^{34}$ Penghitungan rasio keuangan berdasarkan laporan keuangan, diperoleh hasil sebagai berikut:

Tabel 1. Skor Kinerja Perspektif Keuangan

\begin{tabular}{l|r|r|r|r}
\hline Indikator & Rasio (\%) & Nilai & Bobot (\%) & Skor \\
\hline Struktur permodalan & 19 & 3 & 20 & 0,6 \\
\hline
\end{tabular}

\footnotetext{
${ }^{31}$ Heidjrachman dan Suad Husnan. Manajemen Personalia (Yogjakarta: BPFE, 2002), h. 194.

32 Luis, Step by step in cascading balanced scorecard to functional scorecardsS, 90.

33 PINBUK, Peraturan Dasar dan Contoh AD-ART BMT (Jakarta: PINBUK Press, t.t.).

${ }^{34}$ PINBUK.
} 


\begin{tabular}{l|r|r|r|r}
\hline Kualitas aktiva produktif & & & & \\
a. Pembiayaan bermasalah & 7 & 2 & 25 & 0,5 \\
b. Cadangan penghapusan & 6,5 & 1 & 5 & 0,05 \\
\hline Likuiditas & 76 & 3 & 20 & 0,6 \\
\hline Efisiensi & 93 & 1 & 5 & 0,05 \\
a. Biaya Operasional & 41,2 & 2 & 5 & 0,1 \\
b. Nilai Inventaris & 1,2 & 2 & 13 & 0,26 \\
\hline Rentabilitas & 10 & 2 & 7 & 0,14 \\
a. Laba terhadap aktiva & & & $\mathbf{2 , 3}$ \\
b. Laba terhadap modal & & & $\mathbf{2}$ \\
\hline Total skor & & & Kurang Baik \\
\hline Nilai & & &
\end{tabular}

Sumber: Diolah penulis (2020)

Tabel 1 diatas menunjukkan kinerja perspektif keuangan BMT Amanah tergolong kurang baik, terutama pada indikator cadangan penghapusan pembiayaan dan BOPO. Rasio cadangan penghapusan pembiayaan BMT Amanah adalah 6,5\% tergolong tinggi, jauh diatas ketentuan Bank Indonesia yang setidaknya $1 \%{ }^{35}$ Tingginya beban pencadangan aktiva diakibatkan oleh pembiayaan bermasalah (Non Performing Finance, NPF) yang cukup tinggi yakni $7 \% .^{36}$ Pembiayaan bermasalah dapat disebabkan oleh kesalahan lembaga, nasabah maupun faktor eksternal. ${ }^{37}$ Rasio NPF yang baik menurut ketentuan Bank Indonesia melalui PBI Nomor 6/10/PBI/2004 adalah 5\%. ${ }^{38}$ Selanjutnya rasio BOPO BMT Amanah adalah 95\%, masih berada di atas standar BOPO dari Bank Indonesia di bawah 92\%. ${ }^{39}$

\footnotetext{
${ }^{35}$ Maretha Eka Fitriana dan Erman Denny Arfianto, "Analisis Pengaruh NPL, CAR, ROA, LDR dan SIZE terhadap CKPN (Studi Kasus pada Bank Konvensional yang Tercatat di Bursa Efek Indonesia 2010-2014 )," Diponegoro Journal of Management 0, no. 0 (2015): 1.

${ }^{36}$ Medina Almunawwaroh dan Rina Marliana, "Pengaruh CAR,NPF dan FDR Terhadap Profitabilitas Bank Syariah di Indonesia," Amwaluna: Jurnal Ekonomi dan Keuangan Syariah 2, no. 1 (31 Januari 2018): 16, https://doi.org/10.29313/amwaluna.v2i1.3156.

${ }^{37}$ Muhammad Rifqi Hidayat dan Parman Komarudin, "Penanganan Non-Performing Finance Dalam Akad Musyarakah Di Bank Kalsel Syariah," At-Taradhi: Jurnal Studi Ekonomi 9, no. 1 (1 Agustus 2018): 4, https://doi.org/10.18592/at-taradhi.v9i1.2086.

${ }^{38}$ Agus Mujiono, "Penerapan Prinsip Kehati-Hatian Dalam Pembiayaan Dan Kredit Di BRI Unit Mlarak Dan BMT Hasanah Ponorogo," Muslim Heritage 1, no. 1 (15 Mei 2016): 137, https://doi.org/10.21154/muslimheritage.v1i1.386.

39 Duwi Hardianti dan Muhammad Saifi, "Analisis Perbandingan Kinerja Keuangan Bank Umum Konvensional Dan Bank Umum Syariah Berdasarkan Rasio Keuangan Bank (Studi Pada Bank Umum
} 
Hasil pengukuran kinerja keuangan ini sejalan dengan hasil penelitian Almunawaroh dkk., bahwa tingginya rasio pembiayaan bermasalah, cadangan penghapusan pembiayaan dan BOPO berpengaruh negatif terhadap tingkat profitabilitas sehingga berpotensi menurunkan kinerja keuangan BMT. ${ }^{40}$.

\section{Perspektif Pelanggan}

Hasil analisis statistik menunjukkan Weight Score 3,94 dan Highest Scale 5, sehingga indeks kepuasan nasabah atau Customer Satisfaction Indeks (CSI) adalah 0,78 . Indeks retensi nasabah adalah rasio jumlah nasabah berulang (193 orang) terhadap total nasabah (636 orang). Sedangkan customer acquisition adalah rasio nasabah baru (86 orang) terhadap total nasabah (636 orang).

Tabel 2. Skor Kinerja Perspektif Pelanggan

\begin{tabular}{lcccc}
\hline \multicolumn{1}{c}{ Indikator } & Rasio/Indeks & Nilai & Bobot (\%) & Skor \\
\hline Customer Satisfaction & 0,78 & 4 & 40 & 0,16 \\
\hline Customer Retention & 30,3 & 3 & 30 & 0,9 \\
\hline Customer Acquisition & 13,6 & 3 & 30 & 0,9 \\
\hline Total skor & & & & $\mathbf{3 , 4}$ \\
\hline Nilai & & & & $\mathbf{3}$
\end{tabular}

Kategori

Cukup Baik

Sumber: Diolah penulis (2020)

Tabel 2 diatas menunjukkan bahwa kinerja perspektif pelanggan atau nasabah cukup baik. Nasabah merasa puas dengan pelayanan yang diberikan, baik terhadap attributes related to the product, attributes related to the service dan attributes related to the purchase. Kepuasan menjadi penting karena kepuasan merupakan salah satu faktor yang mempengaruhi loyalitas atau kesetiaan nasabah yang salah satu indikatornya adalah tingkat retensi. ${ }^{41}$ Tingkat retensi dan tingkat akuisisi nasabah keduanya tergolong cukup baik. Selain mempertahankan loyalitas nasabah lama, BMT Amanah mampu mengakuisisi nasabah baru.

\section{Perspektif Proses Bisnis Internal}

Rantai nilai utama proses bisnis internal adalah proses inovasi dan proses operasi. BMT sendiri merupakan hasil inovasi, di satu sisi ia memiliki nilai khas dari koperasi yang menjadi ciri lembaga keuangan Indonesia, disisi lainnya ia khas

Konvensional Dan Bank Umum Syariah Yang Terdaftar Dan Diawasi Oleh Otoritas Jasa Keuangan (OJK) Periode 2013 - 2016)," Jurnal Administrasi Bisnis 60, no. 2 (23 Juli 2018): 14.

${ }^{40}$ Almunawwaroh dan Marliana, "Pengaruh CAR,NPF dan FDR Terhadap Profitabilitas Bank Syariah di Indonesia."

${ }^{41}$ Nurintan Asyiah Siregar, "Analisis Faktor-Faktor Yang Mempengaruhi Loyalitas Pelanggan Pasar Dengan Kepuasan Sebagai Variabel Intervening Di Toko Abang-Adik," Jurnal Benefita 4, no. 2 (31 Juli 2019): 366, https://doi.org/10.22216/jbe.v4i2.1555. 
karena mengkombinasikan Baitul Mal yang social oriented dengan Baitul Tamwil yang profit oriented dalam satu lembaga. ${ }^{42}$ Maka, produk pembiayaan sosial Qardul Hasan di dalam portofolio pembiayaan dapat dijadikan indikator proses inovasi. Sedangkan proses operasi berhubungan dengan efisiensi waktu pelayanan dan tingkat kesalahan pelayanan.

Tabel 3. Skor Kinerja Perspektif Proses Bisnis Internal

\begin{tabular}{|c|c|c|c|c|}
\hline Indikator & Rasio/Indeks & Nilai & Bobot (\%) & Skor \\
\hline Pembiayaan Sosial & 0 & 1 & 40 & 0,4 \\
\hline Financing Process Time & 2-7 hari & 4 & 30 & 1,2 \\
\hline Service Error Rate & 37,5 & 2 & 30 & 0,6 \\
\hline Total skor & & & & 2,2 \\
\hline Nilai & & & & 2 \\
\hline Kategori & & & & Kurang Baik \\
\hline
\end{tabular}

Sumber: Diolah penulis (2020)

Tabel 3 di atas menunjukkan bahwa kinerja perspektif bisnis internal kurang baik. Dalam hal proses inovasi, produk pembiayaan sosial Qardul Hasan $0 \%$ menunjukkan bahwa BMT Amanah belum menjalankan kegiatan Baitul Mal. Hal ini tidak sesuai dengan Fatwa DSN No:19/DSN-MUI/IV/2001 bahwa lembaga komersial harus dapat berperan sebagai lembaga sosial yang dapat meningkatkan perekonomian secara maksimal melalui Qardul Hasan yang diberikan kepada nasabah (muqtaridh) yang memerlukan. ${ }^{43}$ Serta ketentuan PINBUK tentang kegiatan operasional BMT yang memiliki ciri khas mengkombinasikan Baitul Mal yang social oriented dengan Baitul Tamwil yang profit oriented dalam satu lembaga. ${ }^{44}$ Selanjutnya dalam hal proses operasi, tabel di atas menunjukkan proses administrasi dan masa tunggu pembiayaan sudah baik sedangkan tingkat kesalahan dalam pelayanan cukup tinggi.

\section{Perspektif Pertumbuhan dan Pembelajaran}

Hasil analisis statistik menunjukkan Weight Score 3,76 dan Highest Scale 5, sehingga indeks kepuasan nasabah atau Employee Satisfaction Indeks (ESI) adalah 0,75 . Employee Turnover adalah rasio karyawan keluar (1 orang) terhadap total karyawan (7 orang). Training Coverage adalah rasio jumlah yang mengikuti pelatihan terhadap total karyawan. Sedangkan absenteeism adalah jumlah ketidakhadiran dalam periode tertentu.

\footnotetext{
42 PINBUK, Peraturan Dasar dan Contoh AD-ART BMT.

${ }^{43}$ Nanda Suryadi dan Yusmila Rani Putri, "Analisis Penerapan Pembiayaan Qardhul Hasan Berdasarkan PSAK Syariah Pada BMT Al Ittihad Rumbai Pekanbaru," Jurnal Tabarru': Islamic Banking and Finance 1, no. 1 (1 Mei 2018): 43, https://doi.org/10.25299/jtb.2018.vol1(1).2043.

${ }^{44}$ PINBUK, Peraturan Dasar dan Contoh AD-ART BMT.
} 
Jurnal Ekonomi Syariah dan Hukum Ekonomi Syariah

Tabel 4. Skor Kinerja Perspektif Proses Pertumbuhan dan Pembelajaran

\begin{tabular}{lrrrr}
\hline \multicolumn{1}{c}{ Indikator } & Rasio/Indeks & Nilai & Bobot (\%) & \multicolumn{2}{c}{ Skor } \\
\hline Employee Satisfacon & 0,75 & 4 & 30 & 1,2 \\
\hline Turnover Karyawan & 14,3 & 4 & 20 & 0,8 \\
\hline Training Coverage & 0 & 1 & 30 & 0,3 \\
\hline Absenteeism & 9,8 & 4 & 20 & 0,8 \\
\hline Total skor & & & & $\mathbf{3 , 1}$ \\
\hline Nilai & & & & Cukup Baik \\
\hline Kategori & & & & $\mathbf{3}$
\end{tabular}

Sumber: Diolah penulis (2020)

Tabel 4 di atas menunjukkan bahwa kinerja perspektif pertumbuhan dan pembelajaran cukup baik. Pelatihan untuk karyawan baru belum terlaksana. Selain hal itu, kepuasan kerja, turnover atau perputaran karyawan dan kehadiran semuanya cukup baik. Tingkat kepuasan kerja menunjukkan bahwa karyawan cukup puas terhadap gaji, keamanan, kenyamanan, penghargaan, kesempatan karir dan kepemimpinan. Kepuasan karyawan berpengaruh negatif atau berbanding terbalik terhadap tingkat turnover, semakin tinggi kepuasan maka tingkat turnover akan semakin rendah (baik). ${ }^{45}$ Demikian halnya dengan tingkat abstensi, semakin tinggi kepuasan maka semakin rendah tingkat ketidakhadiran. ${ }^{46}$

Tabel 5. Kinerja BMT Amanah Menurut Balanced Scorecard

\begin{tabular}{lrrr}
\hline \multicolumn{1}{c}{ Perspektif } & Nilai & Bobot (\%) & \multicolumn{2}{c}{ Skor } \\
\hline Perspektif Keuangan & 2 & 25 & 0,5 \\
\hline Perspektif Pelanggan & 3 & 25 & 0,75 \\
\hline Perspektif Proses Bisnis Internal & 2 & 25 & 0,5 \\
\hline Perspektif Pertumbuhan Pembelajaran & 3 & 25 & 0,75 \\
\hline Total skor & & & $\mathbf{2 , 5}$ \\
\hline Nilai & & & $\mathbf{3}$
\end{tabular}

Sumber: Diolah penulis (2020)

\footnotetext{
${ }^{45}$ Tika Nur Halimah, Aziz Fathoni, dan Maria Magdalena Minarsih, “Pengaruh Job Insecurity, Kepuasan Kerja Dan Lingkungan Kerja Terhadap Turnover Intention Pramuniaga Di Gelael Supermarket (Studi Kasus Pada Gelael Superindo Kota Semarang)," Journal of Management 2, no. 2 (12 Maret 2016), http://jurnal.unpand.ac.id/index.php/MS/article/view/606.

${ }^{46}$ Elida Mahriani, "Pengaruh Stres dan Disiplin Kerja Karyawan terhadap Kepuasan dan Kinerja Karyawan PT. Bank Perkreditan Rakyat (BPR) Mitrathama Arthabuana di Kabupaten Banjar," At-Taradhi: Jurnal Studi Ekonomi 9, no. 1 (1 Agustus 2018): 41, https://doi.org/10.18592/at-taradhi.v9i1.2120.
} 
Kinerja BMT Amanah berdasarkan empat perspektif Balanced Scorecard secara keseluruhan mendapatkan skor 2,5 tergolong cukup baik. Hasil pengukuran kinerja menunjukkan kinerja cukup baik pada perspektif pelanggan dan pertumbuhan pembelajaran. Sedangkan perspektif keuangan dan proses bisnis kinerjanya kurang baik.

Menurut perspektif BSC, sebagaimana telah dijelaskan pada bagian landasan teori di atas, sasaran strategik yang lebih difokuskan ke perspektif pelanggan dan pembelajaran pertumbuhan seperti pada BMT Amanah disebut terlalu berfokus ke orang (people centric), yang mengakibatkan perspektif proses bisnis dan perspektif keuangan menjadi terabaikan.

BSC selalu menekankan pentingnya keseimbangan, karena seluruh perspektif adalah koheren artinya memiliki hubungan sebab-akibat (causal relationship). Setiap sasaran strategik yang ditetapkan dalam perspektif non keuangan harus mempunyai hubungan kausal dengan sasaran keuangan baik secara langsung maupun tidak langsung. ${ }^{47}$ Oleh karena itu, kinerja keuangan yang sesungguhnya adalah kinerja keuangan yang dihasilkan dari perspektif non keuangan (pelanggan, proses internal serta pembelajaran dan pertumbuhan), pengabaian terhadap salah satunya dapat mempengaruhi kinerja keuangan jangka panjang.

Evaluasi kinerja di atas merupakan dasar bagi perumusan sasaran strategik untuk perbaikan pada periode berikutnya yang menekankan diperhatikannya keseimbangan dalam penetapan sasaran-sasaran strategik di keempat perspektif.

\section{Penutup}

Pengukuran kinerja dengan pendekatan BSC pada BMT Amanah yang belum menerapkan BSC dalam pengelolaan manajemen strategik, menunjukkan hasil kinerja yang kurang baik pada perspektif keuangan dan proses bisnis internal, sedangkan pada perspektif pelanggan dan pertumbuhan pembelajaran kinerjanya cukup baik. Hal ini mengindikasikan sasaran strategik yang terlalu berfokus ke orang (people centric), yang mengakibatkan perspektif proses bisnis dan perspektif keuangan menjadi terabaikan.

Hasil evaluasi tersebut dapat dijadikan bahan pertimbangan untuk mengimplementasikan BSC dalam pengelolaan manajemen strategik BMT Amanah, agar sasaran strategis berbasis BSC sehingga lebih komprehensif dan seimbang (aspek finansial dan non finansial) yang akan menghasilkan kinerja keuangan jangka panjang bagi sustainabilitas BMT.

\footnotetext{
${ }^{47}$ Lianto, “Keunggulan Balanced Scorecard Sebagai Sistem Manajemen Strategis Yang Holistik," 1.
} 


\section{Daftar Pustaka}

Almunawwaroh, Medina, dan Rina Marliana. "Pengaruh CAR,NPF dan FDR Terhadap Profitabilitas Bank Syariah di Indonesia." Amwaluna: Jurnal Ekonomi dan Keuangan Syariah 2, no. 1 (31 Januari 2018): 1-17. https://doi.org/10.29313/amwaluna.v2i1.3156.

Atmojo, Cokro Suryo. "The Balanced Scorecard." Diakses 3 Juni 2021. https://www.academia.edu/29202237/The_Balanced_Scorecard.

Dahliana, Difi. "Persepsi Nasabah Terhadap Peran BMT Kota Banjarmasin." Jurnal Al lqtishadiyah 6, no. 1 (1 Juli 2020): 44-51. https://doi.org/10.31602/al.

Fitriana, Maretha Eka, dan Erman Denny Arfianto. "Analisis Pengaruh NPL, CAR, ROA, LDR dan SIZE terhadap CKPN (Studi Kasus pada Bank Konvensional yang Tercatat di Bursa Efek Indonesia 2010-2014 )." Diponegoro Journal of Management 0, no. 0 (2015): 245-52.

Gunawan, Barbara. "Balanced Scorecard: Perspektif Baru Dalam Menilai Kinerja Organisasi." Journal of Accounting and Investment 1, no. 1 (2000): 41-51.

Hadiansah, Deni, Enang Ahmadi, Yayu Nurhayati Rahayu, Rahman Tanjung, Ade Dasmana, Nunung Kurniasih, Arman Maulana, dkk. "Membaca Perspektif Balanced Scorecard," $15 \quad$ Februari 2021. https://repository.azkahafidzmaulana.org/publications/339651/.

Halimah, Tika Nur, Aziz Fathoni, dan Maria Magdalena Minarsih. "Pengaruh Job Insecurity, Kepuasan Kerja Dan Lingkungan Kerja Terhadap Turnover Intention Pramuniaga Di Gelael Supermarket (Studi Kasus Pada Gelael Superindo Kota Semarang)." Journal of Management 2, no. 2 (12 Maret 2016). http://jurnal.unpand.ac.id/index.php/MS/article/view/606.

Hardianti, Duwi, dan Muhammad Saifi. "Analisis Perbandingan Kinerja Keuangan Bank Umum Konvensional Dan Bank Umum Syariah Berdasarkan Rasio Keuangan Bank (Studi Pada Bank Umum Konvensional Dan Bank Umum Syariah Yang Terdaftar Dan Diawasi Oleh Otoritas Jasa Keuangan (OJK) Periode 2013 - 2016)." Jurnal Administrasi Bisnis 60, no. 2 (23 Juli 2018): 10-18.

Herawati. "Pengukuran Kinerja Koperasi Berbsis Balanced Scorecard." Diakses 4 Juni 2021. http://ojs.unik-kediri.ac.id/index.php/ekonika/article/view/33.

Hidayat, Muhammad Rifqi, dan Parman Komarudin. "Penanganan Non-Performing Finance Dalam Akad Musyarakah Di Bank Kalsel Syariah." At-Taradhi: Jurnal Studi Ekonomi 9, no. 1 (2018): 1-9. https://doi.org/10.18592/attaradhi.v9i1.2086.

Huda, Nurul, Ivo Sabrina, dan Efendy Zain. "Pengukuran Kinerja Perbankan Syariah Dengan Pendekatan Balance Scorecard." Etikonomi 12, no. 1 (1 April 2013). https://doi.org/10.15408/etk.v12i1.1900.

Indra, Yus. "Strategi Mewujudkan Kemandirian Sektor Finansial Lokal Melalui Sustainabilitas Lembaga Keuangan Mikro Syariah (Baitul Maal Watamwil, BMT)." 
Jurnal Terapan Abdimas 3, no. 2 (13 Juli 2018): 85-90. https://doi.org/10.25273/jta.v3i2.2793.

Kaplan, Robert S. "Conceptual Foundations of the Balanced Scorecard." Dalam Handbooks of Management Accounting Research, disunting oleh Christopher S. Chapman, Anthony G. Hopwood, dan Michael D. Shields, 3:1253-69. Handbook of Management Accounting Research. Elsevier, 2009. https://doi.org/10.1016/S1751-3243(07)03003-9.

Kaplan, Robert S., dan David P. Norton. Menerapkan Strategi Menjadi Aksi: Balanced Scorecard. Jakarta: Erlangga, 2000.

Lianto, Lianto. "Keunggulan Balanced Scorecard Sebagai Sistem Manajemen Strategis Yang Holistik." MABIS 2, no. 2 (13 Mei 2016). http://journal.widyadharma.ac.id/index.php/mabis/article/view/53.

Luis, Suwardi. Step by step in cascading balanced scorecard to functional scorecardsS. PT. Gramedia Pustaka Utama, 2008.

Mahriani, Elida. "Pengaruh Stres dan Disiplin Kerja Karyawan terhadap Kepuasan dan Kinerja Karyawan PT. Bank Perkreditan Rakyat (BPR) Mitrathama Arthabuana di Kabupaten Banjar." At-Taradhi: Jurnal Studi Ekonomi 9, no. 1 (1 Agustus 2018): 38. https://doi.org/10.18592/at-taradhi.v9i1.2120.

Masyita, Dian. "Islamic microfinance institutions in Indonesia and the challenges in the supply chain perspectives." International Journal of Supply Chain Management 6 (1 Januari 2017): 341-50.

Mujiono, Agus. "Penerapan Prinsip Kehati-Hatian Dalam Pembiayaan Dan Kredit Di BRI Unit Mlarak Dan BMT Hasanah Ponorogo." Muslim Heritage 1, no. 1 (15 Mei 2016): 137-64. https://doi.org/10.21154/muslimheritage.v1i1.386.

Mulyadi. Sistem terpadu pengelolaan kinerja personil berbasis balanced scorecard. UPP STIM YKPN, 2018.

Komite Nasional Ekonomi dan Keuangan Syariah. "Penyusunan Roadmap Pengembangan Baitul Maal Wat Tamwil (BMT) Di Indonesia." Diakses 3 Juni 2021. https://knks.go.id/isuutama/6/penyusunan-roadmap-pengembanganbaitul-maal-wat-tamwil-bmt-di-indonesia.

PINBUK. Peraturan Dasar dan Contoh AD-ART BMT. Jakarta: PINBUK Press, t.t.

Reisfansyah, Muhammad Hiksa, dan Ari Pradhanawati. "Pengukuran Kinerja Perusahaan Dengan Metode Balanced Scorecard Pada BMT Syariah Ar Rahmah Kabupaten Sukoharjo." Jurnal Ilmu Administrasi Bisnis 6, no. 3 (2017): 580-89.

Sharianews.com. "Menyongsong Perkembangan BMT di Indonesia." Sharia News. Diakses 3 Juni 2021. menyongsong-perkembangan-bmt-di-indonesia.

Siregar, Nurintan Asyiah. "Analisis Faktor-Faktor Yang Mempengaruhi Loyalitas Pelanggan Pasar Dengan Kepuasan Sebagai Variabel Intervening Di Toko Abang- 
AL-IQTISHADIYAH

Jurnal Ekonomi Syariah dan Hukum Ekonomi Syariah

Adik." Jurnal Benefita 4, no. 2 (31 Juli 2019): 363-76. https://doi.org/10.22216/jbe.v4i2.1555.

Suryadi, Nanda, dan Yusmila Rani Putri. "Analisis Penerapan Pembiayaan Qardhul Hasan Berdasarkan PSAK Syariah Pada BMT Al Ittihad Rumbai Pekanbaru." Jurnal Tabarru': Islamic Banking and Finance 1, no. 1 (1 Mei 2018): 37-50. https://doi.org/10.25299/jtb.2018.vol1(1).2043.

Ubaidillah, Ubaidillah. "Analisis Sustainabilitas Lembaga Keuangan Mikro Syariah Di Kabupaten Banyumas." Al-Mashrof: Islamic Banking and Finance 2, no. 1 (1 Mei 2021): 76-95.

Utami, Budi. "Pengukuran Kinerja Lembaga Keuangan Syariah BMT As-Salam Dengan Menggunakan Metode Balanced Scorecard." Bisman (Bisnis Dan Manajemen): The Journal of Business and Management 2, no. 1 (22 Februari 2019): 82-93. 